\title{
Hva gjør Tidsskriftets redaksjonskomité?
}

Tidsskrift for Den norske legeforening har hatt en redaksjonskomité siden 1938 (1). Hva slags rolle og hvilke oppgaver komiteen skal ha, har imidlertid ikke vært nedfelt skriftlig. Komiteen arbeider derfor i tråd med sedvane, men både arbeidsform og oppgaver utvikler seg etter hvert som redaktør og komitémedlemmer ser nye behov. Redaksjonskomiteen er et rådgivende organ for redaktøren og redaksjonen. I Legeforeningens lover heter det: «Redaktøren har ved sin side en redaksjonskomité på åtte medlemmer, som oppnevnes av sentralstyret. Seks medlemmer oppnevnes for fire år, likevel slik at tre er på valg i hver sentralstyreperiode. De øvrige to er generalsekretæren og et medlem av sentralstyret» (2). Det er vanlig at sentralstyret oppnevner medlemmer etter forslag fra redaktøren og den sittende redaksjonskomité. Vi som sitter i denne komiteen er alle medlemmer av Legeforeningen, men ikke tillitsvalgte, verken for Legeforeningens medlemmer, for forfattere eller for fagvurderere. Likevel ønsker vi gjennom våre posisjoner innen forskning og forening, og gjennom forskjellig geografisk og faglig tilhørighet, å bidra til å fremme kommunikasjon mellom brukerne av Tidsskriftet og redaktør/redaksjon.

Den sittende redaksjonskomiteen så et behov for å synliggjøre og tydeliggjøre hvilke funksjoner og oppgaver komiteen etter vårt syn bør ha. I løpet av 2008 har vi derfor utarbeidet en «arbeidsbeskrivelse» som vi nå legger ut på Tidsskriftets nettsider (3). Arbeidsbeskrivelsen er dermed tilgjengelig for alle som måtte være interessert, ikke bare i redaksjonskomiteens oppgaver, men også i Tidsskriftets utvikling. Om målsetting for redaksjonskomiteen skriver vi: «Redaksjonskomiteen skal bistå Tidsskriftets redaktør ved å gi råd om strategiske og driftsmessige valg. Dette innebærer også vurdering av Tidsskriftets retning og profil i forhold til de overordnede målsettinger.» Tidsskriftets målsetting er å stimulere til faglig vedlikehold og fornyelse for legen som kliniker, stimulere til medisinsk forskning og fagutvikling, bidra til holdningsdanning hos leger ved å videreutvikle etiske og kulturelle idealer i den medisinske tradisjon, fremme helsepolitisk debatt og være medlemsblad for Den norske legeforening (4). Sammen har altså redaksjonskomiteen og redaktøren valgt en ambisiøs målsetting for komiteens arbeid. På tross av at komiteens medlemmer ikke er en del av redaksjonen og ikke følger den daglige driften på nært hold, skal medlemmene bidra til Tidsskriftets valg av strategi. Hva er vårt grunnlag for en slik funksjon? I våre møter diskuterer vi vanskelige veivalg og avgjørelser. Gjennom slike diskusjoner får komiteen over tid innsikt i sentrale utfordringer, i redaksjonens valg og i deres argumenter for beslutninger. Eksempler på temaer som stadig diskuteres prinsipielt, er dobbeltpublisering - spesielt utfordrende er nettpublisering og intervjuer i massemediene - håndtering av interessekonflikter, vurderingstid for manus og Tidsskriftets økonomiske situasjon.

For å sikre god og regelmessig behandling av saker av stor betydning har vi laget et system for faste temaer på noen av møtene. Fra 2009 vil vi ha en årlig gjennomgang av manusbehandlingstid og evaluering av siste årgang, et tilsvarende årlig møte for diskusjon av strategi og justering av kurs for Tidsskriftet, og et møte med grundigere gjennomgang av den økonomiske situasjonen.

I internasjonale tidsskrifter er det eksempler på at redaktører er sagt opp av eieren fordi man ikke har likt redaktørens redaksjonelle valg. Dette er i strid med redaktørplakaten, som Tidsskriftet har sluttet seg til (5). Redaksjonskomiteen kan både tjene som sentral medspiller for å unngå slike situasjoner og som rådgiver for redaktøren i en eventuell konflikt (6). Selvsagt kan det også oppstå konflikt mellom redaktør og redaksjonskomité, f.eks. dersom redaksjonskomiteen opplever at redaktøren systematisk lar være å følge komiteens råd. I slike situasjoner vil redaksjonskomiteen kunne ta direkte kontakt med Legeforeningens sentralstyre (3).

Redaksjonskomiteen ønsker også å være en kommunikasjonskanal mellom fagmiljøene og redaksjonen. Innspill fra fagmiljøene er derfor en fast sak på våre møter. Henvendelser fra kolleger til enkeltmedlemmer av komiteen tas opp dersom saken har prinsipiell interesse. Det kan dreie seg om behandling av manus, fagvurderinger, utspill fra redaktøren og en rekke andre saker - i den grad de belyser et tema som har interesse for andre enn de involverte. I motsetning til hva mange tror, er redaksjonskomiteen ikke involvert $\mathrm{i}$ behandlingen av manuskripter, heller ikke når det gjelder refusjoner. Unntaket er helt spesielle saker der redaktøren ønsker råd fra redaksjonskomiteen. Vanskelige enkeltsaker som plagiat og fusk blir derimot systematisk drøftet i komiteen.

I utviklingen av arbeidsbeskrivelsen har vi diskutert hva slags forpliktelse vi har til å gi miljøene tilbakemelding på henvendelser. Vårt mandat er å bistå redaktøren med råd og å være et diskusjonsforum med Tidsskriftets målsetting som ledetråd. Sakene som behandles kan være delikate. Det er derfor ikke alltid ønskelig eller nødvendig med full åpenhet. Vi har besluttet at referatene fra møtene fortsatt skal være interne, og tilbakemelding til miljøene vil bli forfattet i samsvar med sakens natur, med individuell vurdering. Saker av bred interesse for Tidsskriftets lesere vil derimot kunne tas opp i en lederartikkel, forfattet av den som spiller inn saken, redaksjonskomiteen eller redaktøren. Dagsorden for komiteens møter vil bli lagt ut på Internett fra og med 2009 (3).

Arbeidsbeskrivelsen som nå ligger på Tidsskriftets nettsider, er et dynamisk dokument i den forstand at det skal og bør revideres etter som tidene og oppgavene forandrer seg. Gjennom arbeidet med dette dokumentet er vi i redaksjonskomiteen blitt mer bevisst vår rolle og funksjon, noe som vi ser som svært nyttig i vårt videre arbeid med å styrke og utvikle Tidsskriftet i samarbeid med redaksjonen.

\section{Guri Rørtveit}

guri.rortveit@isf.uib.no

Annetine Staff, Baard-Christian Schem, Lill-Tove Busund

Karl O. Nakken, Marte Walstad, Ola Dale, Terje Vigen

Tidsskriftets redaksjonskomité

Oppgitte interessekonflikter: Ingen

Litteratur

1. Schiøtz A. Mellom legekunst og vitenskap - Tidsskriftet 1906-56. Tidsskr Nor Lægeforen 2006; 126: 3300-4.

2. Lover for Den norske legeforening. www.legeforeningen.no/ index. gan? $i d=483 \&$ subid $=0$ (9.1.2009).

3. Tidsskriftets redaksjonskomité. www.tidsskriftet.no/redaksjonskomiteen (29.1.2009).

4. Om Tidsskriftet. www.tidsskriftet.no/index.php?nota_id=39 (9.1.2009)

5. Redaktørplakaten. http://presse.no/Pressens_Faglige_Utvalg_PFU/Redaktorplakaten (9.1.2009)

6. Kuehn BM. CMAJ governance overhauled. Firings, resignations, compromised independence cited. JAMA 2006; 296: 1337-8. http://jama.ama-assn.org/cgi/ content/full/296/11/1337 (9.1.2009). 